\title{
Anxieties abound in Europe
}

THE British Government is steeling itself for a decision on whether or not Britain should participate, at an estimated cost of $£ 40$ million a year, in the development of the US manned space station. But it can expect little direct financial help from British industry, which considers that investment in such a long-range project is a matter for the government. Such was the general feeling of participants at a symposium staged two weeks ago by the Department of Trade and Industry (DTI)

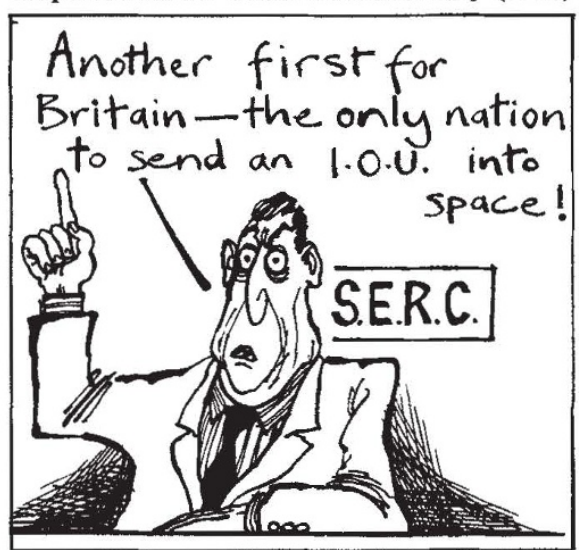

to sound out the views of industry and science.

For the British Government, part of the problem is that space spending will have to increase because of the demands of the European Space Agency (ESA). The agency's Horizon 2000 study earlier this year recommended an increase of the science budget by 7 per cent a year over five years. Britain now contributes $£ 13$ million a year, based on the Gross National Product. Failure to pay the proposed 40 per cent increase by 1990 could exclude Britain from a series of ambitious ESA projects, including a new X-ray observatory, a submillimetre orbiting telescope and a probe to return samples from a comet or asteroid.

The need for extra cash will embarrass the Science and Engineering Council (SERC), whose fixed budget is already under strain and which is already considering whether to strengthen support for general research at the expense, for example, of high-energy physics. Ironically, SERC finds itself facing the prospect of a shortfall in space funds at a time when an internal review group, under the chairmanship of Sir Mark Richmond, is about to recommend greater use of ESA by Britain's space scientists.

By the time science ministers meet in Paris to discuss the long-term goals of ESA, in January next year, Britain's European partners will expect a reaction to both new demands for funds. But, before then, the British Government needs to be convinced of the economic potential of a space station. At the DTI symposium, PA Technology attempted to do just this, presenting the results of a study on the indus- trial processes that stand to benefit from a microgravity environment. It pinpointed two principal areas: the fabrication of defect-free semiconductor crystals and the preparation of extra large protein crystals. PA Technology says that the latter could benefit the enzyme business by allowing molecular structures to be defined quickly and efficiently.

Even so, British high-technology companies are sceptical of the benefits and of the speed with which they would emerge. The cost of the space station is estimated at $\$ 8,000$ million (1982 prices); the United States hopes that $15-20$ per cent will be contributed by Europe and Japan.

PA Technology also argued at the DTI symposium that participation in the space station would stimulate industrial research in areas such as robotics, computer design and materials manufacture. British Aerospace has endorsed this view, presenting, at the DTI symposium, specific plans for an unmanned platform, launched by the US shuttle, to which Britain might contribute
40 per cent of the cost. This plan would complement rather than duplicate the US manned space station, says the company, which claims that the National Aeronautics and Space Administration has already responded enthusiastically to the suggestion.

Elsewhere in Europe, there are more subversive views. Strong bodies of opinion in West Germany and Italy are pushing for an independent European space station, perhaps to work in conjunction with a US platform. This idea, called Columbus, is being widely discussed within ESA and reflects a feeling abroad in Europe that greater autonomy is necessary. Buoyed by the successes of Ariane and Spacelab, many aerospace companies are eager to show that they can function independently of the United States.

The United States expects firm proposals for European collaboration in the space station by the end of 1985 , and will want to know how the work would be divided between participating nations, which may include Japan and Canada as well as European states, acting either independently or in concert through ESA, by mid-1986.

Marcus Chown

\section{UK Australian nuclear tests}

\section{Inquiry stirs fallen dust}

ON 16 October, the president of the Royal Commission inquiring into British nuclear testing in Australia, Mr Justice James McClelland, urged that if the British Government wished to have its views accurately represented, it would be well advised to appear before the commission. The newly-installed British High Commissioner to Australia, Sir John Leahy, had earlier expressed concern about the recent public allegations that the British authorities had disregarded the safety of aborigines and atomic personnel.

The present official silence, Sir John said, must not be interpreted as tacit admission to the charges laid, that the decision to present evidence would be taken in London and that it would depend upon "how the commission goes about its business in future"'. Mr Justice McClelland replied that the Royal Commission could not be expected to forbid publication of allegations discomfiting to the British Government.

So far the allegations claim that unprotected servicemen flew sorties through radioactive clouds, that they decontaminated aircraft after the tests, that servicemen had buried the corpses of aborigines found on the range, that mentally-retarded civilians were placed in bunkers near a Maralinga blast in 1956 (see Nature 310,$90 ; 1984)$ and that servicemen were used as guinea pigs (see Nature 309, $199 ; 1984)$, a claim stressed by counsel for the British Nuclear Test Veterans Association.

On 3 October, the three royal commissioners also heard an account of the discovery and attempted decontamination of a family of four aborigines who, it was alleged, had camped for a few days in the Marcoo bomb crater seven months after the 1956 Maralinga blast, in apparent contradiction to a report in January 1983 of the same event by the Australian Ionizing Radiation Advisory Council (AIRAC). Servicemen who had witnessed the event were told by a British officer that disclosure would result in court-martial and possibly the firing squad.

The commission's charter includes investigation of the safety measures taken before, during and after the tests, whether health had been affected, and the nature and size of the devices tested in the twelve major explosions and an unknown number of "'minor trials"' known as Rats, Kittens, Ayres, Tims and Vixens.

Last week, the federal government refused a request from the Australian Nuclear Veterans for legal aid to challenge the credentials of royal commissioner Mrs Jill Fitch. A conflict of interest arose, they asserted, from her continued membership of both the commission and AIRAC, since it was criticism by Professor Charles B. Kerr's committee in May this year of AIRAC's treatment of fall-out data which led to the commencement of the Royal Commission.

The commission is due to report in June 1985 and has applied to the British Government to take evidence in Britain later this year.

Jeffrey Sellar 